\title{
22. Fiscal and monetary responses to the COVID-19 pandemic: Some thoughts for developing countries and the international community
}

\section{Eugenio Díaz-Bonilla}

Most developed countries have implemented massive economic responses to the COVID-19 pandemic, ramping up spending and using monetary policy to cushion the blow of lockdowns and other measures that have shut down businesses and left huge numbers unemployed. But for developing countries, which are now starting to respond to the crisis more aggressively, such options may be more limited. Here I discuss some ideas for how these countries may address the economic fallout, and how international organizations can help.

\section{Addressing the crisis in developing countries}

Developing countries should start by implementing a national response plan focusing on these four interrelated spheres: health; the supply and demand of essential goods and services; the domestic financial circuit in local currency; and the foreign currency market, linked to international trade and external debt. Such a plan requires a centralized crisis-management office led by the president, prime minister, or equivalent, with participation of the relevant public and private sector representatives. This is easier said than done, but it is the only way to avoid uncoordinated actions and working at cross purposes.

Here I will focus on the latter three spheres, acknowledging that there are interactions with health measures, as well as short-term trade-offs between health controls and economic activity.

\section{Supply and demand of essential goods and services}

Governments must address basic supply and demand issues to prevent shortages, price spikes, and economic disruptions in the short term. It is essential to ensure the production and distribution of food and medicines, which in turn requires keeping transportation and basic public services (water, energy, and communications) up and running. The crisis-management office must establish committees with the private sector and operators in key areas to monitor daily the flow of crucial goods and services, and the health of workers and critical personnel. Bottlenecks, as well as hoarding and unfair trade practices, must be monitored and energetically addressed.

Regarding demand, governments must enact initiatives to support employment and income, including expanding safety nets with a food component. Central banks can play a key role, pursuing 
unconventional monetary policies that establish various channels to inject liquidity into the economy (I discussed several options in Díaz-Bonilla 2016 and 2018, for a different context). Of course, developing countries with a very strong fiscal position pre-COVID-19 may be able to borrow in domestic and foreign currency, without immediately resorting to the approaches discussed. What follows assumes that such is not the case in most developing countries.

\section{The domestic financial circuit in local currency}

Supporting supply and demand for basic goods and services will require an expansion of the money supply (see Díaz-Bonilla 2015). Central banks must dust off the instruments they used when they were called "developmental central banks." This means taking steps that exceed recent monetary interventions, and which may raise objections.

The recent expansion of the "quantitative easing" approach to increase money supply has nonetheless remained more limited in scope and impact than past options, in developed as well as in developing countries (see a general discussion in Epstein 2005; the specific case of the US Federal Reserve is in Fettig 2008). In fact, the process of creating "modern" central banks has mostly involved restricting monetary instruments, mainly because of concerns about their past use (and abuse) leading to high inflation in many developing countries; because they may amount to picking winners and losers; and, perhaps, because of distributive effects. The latter two effects are unavoidable with any monetary mechanism, however indirect (see Coibion et al. 2012).

Nevertheless, central banks must expand their options for lending to the private sector and to the government.

Part of the private sector support can be offered through rediscount credit lines to banks so that they, in turn, may maintain soft lines of credit for the working capital of companies, especially small and medium-sized enterprises (SMEs), including small and family farms. Those soft rediscount lines (or even outright grants, using a non-bank channel) should require businesses to keep employees on the payroll. In particular, these lines of credit could be crucial to support operators in food systems (especially family farmers), the health sector, and other crucial activities.

Central banks can also finance the public sector directly, with the objective of expanding food programs and safety nets (including considering some form of universal income), supporting the operation of the health system, financing other basic services, and investing in public works. These initiatives will definitely expand the money supply. That in turn requires eliminating or reducing other sources of money creation, on the one hand, and trying to align the supply and demand for local currency, on the other. The latter is necessary to avoid a spike in inflation and/or a currency run (discussed below).

If the supply of basic goods and services is ensured, as discussed above, inflation risks will be reduced. Also, the economic deceleration or recession from the pandemic shock, and the increase in what economists call the need for "precautionary balances" or more savings by households and individuals, would work against an inflationary shock. 
During this process, the banking system must be monitored continuously to ensure its proper functioning. There will be need of some flexibility for debtors, but also for the banks when they are evaluated and audited by the central bank or equivalent authority.

\section{Supply and demand for foreign currency}

To avoid a run on the domestic currency from the expanded money supply, governments will most likely have to establish controls on transactions in foreign currency. The government must be able to manage foreign reserves, calculating the cash flow needed to finance the imports of food, medicines, energy, and other basic materials for at least six months, while considering the net flows of external debt.

One crucial consideration: avoiding an overvalued official exchange rate. Many developing countries' exports will decline in price and quantity due to lower world demand, and remittances will also be affected. Addressing that shock requires maintaining an official exchange rate valuation that does not discourage exports needed to finance crucial imports and other external flows. Also, developing countries may reduce import taxes for critical goods (to alleviate inflationary pressures), while refraining from export bans on food and other basic products.

\section{The role of international organizations}

During the 2008-2009 crisis, the G20 suggested a variety of domestic and international measures to confront the global recession. Domestically, it called for strong monetary and fiscal stimulus. Internationally, it expanded the capital base and operations of the international financial organizations. Now that developed countries are taking stronger and more unconventional monetary approaches, the G20 and the United Nations (UN) should respond vigorously on behalf of developing countries.

International organizations must call for further rounds of "unconventional monetary policies" coordinated with fiscal stimulus in developing countries, as discussed above, allowing them the policy space to decide how to do this (in many countries, this would most likely mean separating the local and foreign currency markets). They should also encourage leaders in developing countries to establish a central crisis management office as outlined above.

Those domestic responses must be supported by international action from the UN and the G20:

- Increases in capital at the International Monetary Fund (IMF) and multilateral development banks (MDBs) (at least the same amount as in 2008-2009). This will take time to negotiate, so the MDBs can be asked to adjust their financial policies to be able to increase their loans/equity ratios (say, up to 5 or somewhat more). This will require establishing the regulatory mechanisms and dialogue with credit rating agencies to adjust their criteria for risk rating, so these changes do not lead to downgrades of ratings of the MDBs, which would constrain their lending capabilities just in the middle of the recession. The additional lending capacity in MDBs should focus mainly on financing the health budget of developing countries; strengthening safety nets; financing food supply and distribution; and financing working capital for SMEs. 
- An additional allocation of special drawing rights (SDRs) to about double the amount of 2008-2009.

- Establishing a mechanism of debt resolution for developing countries focusing, at least, on the debt coming due in the next two years. At a minimum, it is necessary to ensure neutral capital flows with MDBs and bilateral financial agencies, along with the rollover of private debt coming due in that period. Many developing countries will need further support due to larger trade deficits and declining remittances.

- Directing MDBs to enter into conversations with private sector banks and investors to establish different mechanisms of co-lending (such as what are called A/B loans, selling part of the developmental portfolio, and similar options).

- Directing the UN agencies and the MDBs to set up mechanisms to advise and support developing countries in their policy responses within the health sphere and in the real-economy sphere, particularly food, medicines and health equipment, energy, and basic public services.

It would also help if expanded liquidity swaps (as done in 2008-2009) could be established by central banks across a larger number of developed and developing countries. Initial movements in that direction are underway.

\section{Conclusion}

These historically unprecedented times require unconventional responses. Yes, there are several examples of countries that in the past have abused "unconventional monetary approaches," leading to high bouts of inflation, strong devaluations, balance of payment crises, and corruption. Yet, with prudence, these approaches should now be used to finance specific public expenditures, such as cash transfers and safety nets for the poor and vulnerable, and certain public investments, and to keep firms operating. In any case, money always enters into the economy through specific actors (at present, mainly the owners of the assets being bought by the central banks), and not by equally endowing each citizen with the same amount of currency (as in Milton Friedman's parable of "helicopter money"). A universal income would do the latter, and some of the recent rescue packages in developed countries moved in that direction. The methods suggested here would ultimately make the channels through which an expanded money supply gets into the economy more democratic.

The international community must also step up its response as outlined above.

The situation is very complicated, and the world will not be the same after this crisis. It is in our hands to limit the global damage and to establish the foundations for a strong rebound afterward.

Some of these ideas appeared in an article in Clarín (Buenos Aires).

Originally published April 5, 2020. 